\title{
Self-Regulation Of The Qur'an Reciters Student
}

\author{
Nelly Marhayati, Pasmah Chandra, Ayu Indah Lestari \\ IAIN Bengkulu \\ Corresponding Author: nellymarhayati@iainbengkulu.ac.id
}

\begin{abstract}
The purpose of this study was to find out how the process of self-regulation of Qur'an reciters tutors at Ma'had al-Jami'ah IAIN Bengkulu. This research used descriptive qualitative method by involving 12 student as respondens who have completed memorizing more than $5 \mathrm{Juz}$ and are currently in $5^{\text {th }}$ and $7^{\text {th }}$ semsester. Data collected through interviews, observation, and documentation. It was found that two factors form self-regulation of Qur'an reciter students. Internal factors are self-observation, judgmental process, and self-response. The external factor is support from a closed family. In addition, there are supporting and inhibiting factors in the self-regulation process. Supporting factors in the form of an intention to memorize, have a memorizing target, and strong motivation and support from the closest people. The inhibiting factors are laziness, finding difficult vocabulary, gadgets, and negative mood disorders.
\end{abstract}

Keywords: Self Regulation, Qur'an Reciter Students

\begin{tabular}{|c|c|c|c|c|}
\hline Submission & Review Process & Revised & Accepted & Published \\
\hline December 16, 2020 & $\begin{array}{c}\text { June 14, 2021 - June } \\
21,2021\end{array}$ & June 21, 2021 & June 21, 2021 & June 30, 2021 \\
\hline
\end{tabular}

\section{Introduction}

Qur'an recitersmeans keeping the Qur'an in the heart and making the Qur'an the most important thing to do every day, every morning, every afternoon, evening, and even night. (Amen, 2016). Qur'an reciters must always repeat their memorization and guard themselves against various sins and disobedience. Qur'an reciters realizes that sin and the Qur'an will not unite in itself. Qur'an reciters realizes that disobedience can remove the Qur'an from his heart. Therefore, Qur'an reciters can indirectly protect one's self from bad behavior (Lukmawati et al., 2018).

Qur'an reciters requires a strong memory and must be accompanied by care and repetition (muraja'ah) so that it is not easy to forget. The same applies to students who memorize the Qur'an. The phenomenon of students who decide to become memorizers of the Qur'an is certainly very interesting to know more deeply. Through in-depth observations, it is hoped that researchers will be able to find out how students who memorize the Qur'an balance and control themselves between campus obligations and the obligation to memorize the Qur'an.

Several factors influence the memorization of the Qur'an, including motivation, health, age, hard work, physical and spiritual readiness, willingness, and strict self-regulation. Strict self-regulation in psychological terms is referred to selfregulation.

Referring to several previous studies (Lasmiati, 2018) (Hapidoh, S., Bukhori, B., \& Sessiani, 2019) who examined the selfregulation of students who memorized the Qur'an showed that the self-regulation of students who memorized the Qur'an was different from students who did not memorize the Qur'an. Students who memorize the Qur'an are better in their self-regulation skills even in the final semester to completing their thesis. However, some of these studies are quantitative point of view, so that only 
knowing the degree or size of student selfregulation has not been deep into the causal factors and even the real form of selfregulation of students who memorize the Qur'an itself.

Bandura (in Alwisol, 2012) stated that self-regulation is the ability of individuals to regulate themselves in achieving the desired target. This ability will affect the process and results of the efforts carried out by the individual. If the individual can manage himself well, then he will get the results as targeted. On the other hand, if the individual cannot manage himself properly, then the desired target will not be achieved. (Baumeister \& Vhos, 2007) states that selfregulation is an important personality process when a person tries to control their thoughts, feelings, impulses, and desires as well as their performance. Another opinion states that selfregulation concerns a personal capacity that is internally directed to regulate emotions, attention, and behavior to respond effectively to internal and environmental demands.

The purpose of this study was to describe the form of student self-regulation and also to determine the factors that influence student self-regulation at Ma'had Al-Jami'ah IAIN Bengkulu. Students who memorize the Qur'an at Ma'had Al-Jami'ah are commonly referred to as Mahasantri (a student). Mahasantri certainly understands the consequences of memorizing the Qur'an.

In addition to students having to maintain their daily behavior, a student who is considered a reflection of the Qur'an should be able to maintain attitudes and behavior in their daily behavior so that it will indirectly form social control within themselves. There are not many students in the modern era when compared to the student population on campus or university. Likewise at IAIN Bengkulu, some students have the desire and opportunity to learn to memorize the Qur'an. Students who wish to become mahasantri will be placed in a dormitory known as Ma'had al-jami'ah IAIN Bengkulu. Mahasantri is not only from upperlevel or senior-level students in terms of semesters but also from lower-level or new students studying at IAIN Bengkulu. Most of the students who have lived and studied at Ma'had al-Jami'ah have proud achievements and good memorization.

A student who also memorizes the Qur'an can be categorized as a student who has many roles. It's the same with students who act at the same time as housewives and work (Rachmah, 2015) and students who act as members of organizations on campus (Setiyawati, 2019). Therefore, it is interesting to study how they self-regulate in completing campus assignments with their obligation to complete the memorization of the Qur'an assigned to students.

\section{Self Regulation}

Self-regulation according to terminology means that individuals can motivate themselves, set personal goals, plan strategies, to improve and modify behavior. Self-regulation includes not only activities to start achieving goals but also avoiding environmental disturbances and emotional impulses that can interfere with a person's development (Cervone, \& Pervin, 2012).

Bandura (1989) states that selfregulation is the ability to regulate behavior and carry out that behavior as a strategy that affects a person's performance in achieving goals or achievements as evidence of increasing behavioral performance. Albert Bandura was one of the behaviorists who added a cognitive aspect to his thinking about behaviorism. The development of the theory has been carried out since 1960 and refers to Skinner's view. However, Bandura has his assumptions regarding human nature and personality. The assumptions are:

a. Humans are essentially conscious beings, think, feel and regulate their behavior. Thus, humans do not mean pawns or 
pawns that are easily influenced or manipulated by the environment. The relationship between humans and the environment are mutually influencing one another.

b. Personality develops in a social context, the interaction between each other. Thus, the right personality theory considers the social context.

Bandura's social learning theory of personality is based on the formula that human behavior is the result of continuous reciprocal interactions between determinants: internal (cognition, perception, and other factors that influence human activities), and external (environment). This process is called "reciprocal determinism", which means that humans influence their destiny by controlling environmental forces, but they are also controlled by environmental forces. (Yusuf \& Nurikhsan, 2013).

According to Zimmerman (Zimmerman \& Schunk, 2001), self-regulation includes three aspects that are applied in learning, i.e:

a. Metacognitive is understanding and awareness of cognitive processes or thinking. Metacognition is an important process because a person's understanding of his cognition can guide individuals to organize and organize events to be faced and choose appropriate strategies to improve their cognitive work in the future.

b. Motivation is a function of the basic need to control what will be done and is closely related to the abilities that exist in each individual.

c. Behavior is an individual's effort to selfregulate, select, utilize, and create an environment so that it can support the activities that will be carried out by individuals.
Based on the description above, it can be said that individual self-regulation will be influenced by several things which will determine how the individual process in achieving his goals. It is also inseparable from the assessment process based on moral and social standards. In addition, the selfregulation of an individual is also determined by the reaction of self-evaluation to what things will and have been done.

\section{Memorizing the Qur'an}

Qur'an reciters is a coaching process that not only requires adequate cognitive abilities but also requires strength of determination and straight intentions. Qur'an recitersis a process that involves many parties, not only the coaching process for oneself but also the people. It is conceivable that amid this ummah there are many memorizers of the Qur'an who adorn themselves with very special qualities and characters. It is undeniable that such people will always live and triumph and will never die (Muhsin \& As-Sirjani, 2017).

As stated by Lisya Chairani the following: "The memorizer of the Qur'an is obliged to maintain his memorization, understand what he has learned and be responsible for practicing it. Therefore, the memorization process is said to be a long process because the responsibility carried by the memorizer of the Qur'an is attached to him until the end of his life. The obstacles that often occur when Qur'an reciters are boredom in memorizing the Qur'an, low motivation, romantic disorders, difficulty memorizing. (Chairani, \& Subandi, 2010)

Sa'dulloh revealed that the efforts to preserve the Qur'an by some human beings have continued from the time of the companions to the present day. This is done in addition to maintaining the authenticity of the Qur'an, it can also thwart attempts to falsify the Qur'an. Reading the Qur'an is an act of worship, as well as learning to explore the meaning of its contents, let alone trying to 
memorize it, it is perfect worship. (Sa'dulloh, 2008)

Al-Qur'an according to Abu Syuhbah is the mashdar form of the verb qara'a, meaning "reading". This word later became the holy book that was revealed by Allah SWT to the Prophet Muhammad SAW. While the Qur'an according to the term is the word of Allah SWT revealed to the Prophet Muhammad SAW who has miraculous pronunciation, reading it is worth worship, narrated mutawatir, written in manuscripts, starting from Surah Al-Fatihah and ending with Surah An-Nass.(Al-Munawar, 2002).

Muhammad Roihan Daulay in his writings mentions that the Qur'an revealed by Allah to the Prophet Muhammad SAW is not only the holy book of Muslims but also as the greatest miracle among the miracles of other prophets. The revelation of the Qur'an in a period of 23 years is divided into two phases. First, the verses that were revealed in Mecca are called Makiyah verses. Second, they were revealed in Medina which is called the Madaniyah verses. Al-Qur'an as the last book is intended to be a guide for all mankind (hudan linnas) until the end of time. The Qur'an is not only intended for the Arab community where this book was revealed but also for all human being. (Daulay, 2014).

The term Al-Qur'an itself went through a long process before the holy book was named so. Jalal al-Din-al-Suyuthi, in al-Itqan fi 'Ulum al-Qur'an, explains that Muslims after the death of the Prophet differed in opinion about how best to call their holy book. Some of them suggested the name "Injil" (referring to the Christian tradition), others suggested the name "Sifr" (referring to the Jewish tradition). Abdullah ibn Mas'ud, one of the closest companions of the Prophet proposed the name "Mushaf" which later this proposal was widely used by Muslims to refer to their holy book. (Ghazali \& Abdalla, 2009).
The term "mushaf" is more of a generic word than a technique. This word is taken from the Ethiopian people (Habsyah) who have long used the term to refer to a collection of recorded Bibles. In the early Islamic tradition, the term Mushaf later became a technical term to refer to "a collection of Allah's verses that were recorded or bound". In English literature, the term Mushaf is usually called a " kodeks" (codex).

\section{Research Methods}

The object of this research is the students who memorize the Qur'an at Ma'had Al-Jami'ah IAIN Bengkulu. This research is qualitative research with field research type. This qualitative approach method is also called the naturalistic research method because this research is carried out in natural conditions (natural settings). The focus of this research is to explore the steps or ways that students at Ma'ahad Al-Jami'ah do in self-regulating between campus assignments and the obligation to memorize the Qur'an.

Data collection technique used purposive sampling, namely the selection of informants using certain criteria. The criteria for informants in this study are:

- 3 rd, 5th, and 7th-semester students

- live in Ma'had al-Jami'ah.

- has memorized the Qur'an more than 5 Juz.

Based on the criteria above, 12 informants were selected for this study.

Data collection techniques in this study using interviews with 12 informants and direct observation and by using additional data from the profile book of Ma'had Al-Jami'ah IAIN Bengkulu. Interviews were conducted referring to the interview guidelines regarding self-regulation of students memorizing the Qur'an.

The data in this study have been analyzed by data triangulation process against 
the data that has been collected previously. Furthermore, after going through the data triangulation process, it was found the stages of forming student self-regulation at Ma'had Al-Jami'ah IAIN Bengkulu.

\section{Results and Discussion}

Based on Bandura's previous opinion that human behavior is the result of continuous reciprocal interaction between the determining factors, namely internal factors, and external factors. Similarly, the formation of selfregulation, influenced by internal and external factors. The steps are taken in the process of forming self-regulation in this case internal factors include: self-observation, the process of evaluating or judging behavior (judgmental process), and self-affective reactions (selfresponse). In this section, the results and discussion of the findings in the field will be presented concerning internal factors and external factors that make up the regulation of students of Ma'had Al-Jami'ah IAIN Bengkulu.

\section{A. Internal factors}

\section{a. Self-observation}

Associated with the individual's assessment of self-efficacy and cognitive work to choose the appropriate strategy for the abilities possessed. It was found that the students did, among other things, not often compare themselves with others, did not hesitate to ask for opinions from others, and met the targets set or determined by the supervisor. This is as stated by one of the informants: "The way I assess my ability, that is by not comparing myself with others, then I will find that ability. Also don't ever feel arrogant, because above the sky there is still a sky ". (Interview with informant Ega, 23 December 2019)

This opinion is supported by the opinion of other informants: "I will ask other people or closest friends. Because the real judge is someone else. If we judge from our point of view, we may think that we are perfect or even worse than others. (Interview with informant Ajeng, 23 December 2019)

Based on the answers from these informants, the researcher got the idea that it is very important to believe in yourself with all your abilities. Because if you compare yourself with others, you will feel two possibilities. First, they will feel very capable compared to other people, or second, the individual will feel insecure or inferior to his abilities.

The individual's ability to self-assess (self-observation) is the initial stage of one's ability to self-regulate. This stage must be done before proceeding to the next process. Like the research conducted by Yasdar and Muliyadi (2018) on self-regulation techniques in the application of student self-study. where students who have been able to assess themselves still have to imitate and receive guidance from the teacher. In addition, Wahyuni's research (2012) explains that although individuals can understand themselves in this case understanding individual anger, individuals still need further processes to improve their ability to manage anger. In this study, the skill that must be possessed is the restructuring of internal dialogue.

The same is true for mahasantri. The ability to self-assess can also be done by meeting predetermined targets, namely depositing memorization or repeating past memorization. The observations made by the researchers showed that the way these memorizing students assessed their abilities was by meeting the daily memorization target and depositing them with the ma'had teacher. Then another way they do this is by asking and mutual muroja'ah to their fellow Qur'an memorizers.

However, this process must be continued with the next process to produce good self-regulation.

\section{b. Judgmental process}

The second process carried out by students in forming self-regulation is to carry out a process of assessing and adjudicating behavior (judgmental process). Assessment of self-behavior is by looking at whether the behavior is following personal standards or 
with existing norms or with the standards of others. See also whether the activities carried out are important and give attribution to individual performance (Alwisol, 2012)

For students, the judgmental process is done by regulating the environment so that they can provide support so that students can memorize well. As social beings, of course, humans cannot be separated from the interaction with other humans. This process is closely related to the assessment and support of the community and the environment. Likewise, students who memorize the Qur'an, besides being required to meet the targets that have been set, must also continue to interact well with the surrounding environment, especially their college friends, so they must determine their attitude towards the environment so that they can memorize well.

As explained by one of the following informants; "My attitude towards the environment so that I can keep memorizing is keeping what I must guard, meaning not too rigid and not too free in association" (Interview with Yomi informant, 24 December 2019)

The same thing was also conveyed by other informants: "My attitude towards the environment to keep memorizing well is to try to adapt and keep limiting the environment that is not supposed to be." (Interview with informant Anna, 24 December 2019)

The observations made by the researchers showed that to protect themselves from unwanted actions, students tend to limit themselves to the environment and activities that they should not. For example, by not following the style of excessive interaction with something and prioritizing memorizing rather than spending time outside the Ma'had environment.

Based on the observations and explanations from several sources above, it can be concluded that the attitude towards the environment to keep memorizing well is to limit oneself from inappropriate associations and maintain what should be guarded. Choosing friends is very necessary to form a comfortable environment for students who memorizing the Qur'an, so it does not interfere with their memorization activities.

\section{c. Self-response}

Self-response is done in two ways, namely self-evaluation and self-rebuke. For self-evaluation carried out by informants is by evaluating yourself, it is hoped that you can take useful lessons on each side. As explained by the following informants: "The selfevaluation I did was to improve my memorization of the Qur'an, read more of the Qur'an, study and learn all things about the Qur'an" (Interview with informant Yurike, 24 December 2019).

As a student who memorizes the Qur'an, of course, a good and correct reading of the Qur'an is needed, therefore, continuing to improve and multiply reading the Qur'an will reduce mistakes made in the memorization process. This is supported by the following informants' answers: "I evaluate myself on the things that have been done before by learning from mistakes, giving advice to myself and learning from others" (Interview with informant Anna, 23 December 2019).

Every experience that has been passed by humans is the best teacher for the individual concerned. Based on this experience, will be known the location of the mistakes that have been passed and this experience is also used as a tool for self-evaluation. Furthermore, to evaluate yourself you can also learn from others. As explained by the following informants: "I evaluate myself by always learning from the people around me. Never be complacent" (Interview with informant Intan, 25 December 2019).

Based on the observations made by the researchers regarding the self-evaluation carried out by the students who memorized the Qur'an, it showed that the students did not hesitate to ask other memorizers about themselves, especially about the achievement of their memorization, then after knowing the part that was considered wrong, the student will try to fix it.

As for the reprimand to oneself, it must be better than yesterday, using free time to memorize, for example, during class time.

As explained by one of the following informants: "There are so many reprimands for my negligence, both internal and external. Internally in the form of motivational speech to 
myself, I must be better than yesterday. Meanwhile, from external influences, friends come out with motivational words, if my friend can do it, I should be able to do it too". (Interview with informant Sintia, 25 December 2019).

The reprimand to the informant is more about growing motivation by looking at the surrounding environment and making today better than the previous day.

In addition, in addition to using free time in class, giving appreciation to yourself is done as an appreciation to yourself for having succeeded in meeting the target. Giving rewards to yourself can be done by buying food or clothes you like. As the following informant said: "The rebuke I gave myself was to use my free time, such as in class to memorize, and also to give advice to myself. While the appreciation I give to myself is in the form of having fun by buying food or clothes that I like." (Interview with informant Sindi, 25 December 2019)

The stages of self-response carried out by students are following the stages of the selfregulation process from Bandura (in Alwisol, 2012) where individuals at this stage can assess themselves whether what they are doing is positive or negative. If positive will give rewards to yourself if negative will give punishment to yourself.

\section{B. External Factors}

External factors are factors that come from outside the individual, can be in the form of environmental support and also how to manage the environment so that they can memorize the Qur'an as previously targeted. Based on the results in the field, it was found that the greatest support was obtained from the closest people, especially parents. As the results of the interview below: "The support given by the people closest to me is motivation and advice. Especially from my parents, although not in concrete terms, I know that you always pray for the best for me." (Interview with informant Ajeng 23 December 2019).

Not much different from the previous informants, the following informants also gave their responses: "My parents support me in memorizing the Qur'an, they always support me and pray for me" (Interview with informant Yomi, 24 December 2019).

Based on the answers from the informants above, the researcher can illustrate that the support and advice from the closest people, especially parents, play a very large role in the process of forming self-regulation for students who memorize the Qur'an. The support and advice from parents is a very important motivation for the continuity of memorizing the memorizing students because indeed some of them intend to memorize is to give the crown of honor for having succeeded in Qur'an recitersto their parents in the hereafter.

Based on the findings in the field, both the results of interviews and field observations about self-regulation in Ma'ahad Al-Jami'ah students, it can be described as follows. The self-regulation of the students who memorized the Qur'an in Ma'had is influenced by two factors, namely internal factors in the form of self-observation, judgmental process, and selfresponse. In addition to internal factors, selfregulation is also influenced by external factors in the form of support from the closest people.

Self-regulation is the ability possessed by individuals to regulate and control themselves and the surrounding environment to achieve the targets that have been set. In this study, the self-regulation that wanted to be known as the students who memorized the Qur'an at Ma'had Al-Jami'ah IAIN Bengkulu. In addition to acting as memorizers, these students are students who are currently studying at IAIN Bengkulu. So that the division of time between memorizing and studying lecture material is very important to note. The role of the environment that affects the individual and how the individual behaves towards the surrounding environment becomes 
an external factor in the formation of student self-regulation.

\section{Supporting and Inhibiting Factors}

Based on the data in the field, it was found that there were supporting factors that played an important role in the process of forming student self-regulation, including the support from the campus in the form of providing dormitories or also called Ma'had which was specially prepared for students who memorized the Qur'an to live. The aim is to support good interaction between fellow students who memorize the Qur'an.

In addition, the success key of students Qur'an recitersis also motivated by their intention to memorize, have strong motivation, have a target of memorizing and know the purpose of memorizing the Qur'an, and of course support from both parents. The results of this study support previous research conducted by (Marza, 2017) about the factors that support adolescents Qur'an reciters in Islamic boarding schools. Namely the intention of steadfastness in memorizing the Qur'an, goals, and sources of motivation.

In addition to supporting factors, there are also inhibiting factors in the process of Qur'an recitersfor students, namely the feeling of being lazy to memorize and also finding difficult vocabulary and this will make it difficult for students to memorize. Another inhibiting factor that has a large influence on student self-regulation in memorizing is the temptation of using gadgets and the presence of mood disorders.

The inhibiting factors found in this study, especially in terms of interference from the use of gadgets, were not found in previous research conducted by Utami and Hidayat (2017) on the self-regulation of adolescents who memorized the Qur'an. Similarly, mood disorders were not found in previous studies (Utami, \& Hidayat, 2017). The existence of mood disorders in female students may be related to the gender of the informants studied, because this study was only devoted to female students, so that mood disorders were found due to hormonal influences every month (menstruation) as one of the inhibiting factors in managing student self-regulation at Ma' had Al-Jami'ah.

\section{Conclusion}

Based on the results of the research and discussion, it can be concluded that the process of forming self-regulation of students Qur'an reciters at Ma'had Al-Jami'ah IAIN Bengkulu is influenced by internal and external factors. Internal factors in the form of self-observation (not comparing oneself with others, asking others, targeting memorization, and depositing memorization, judgmental process (regulating the environment), and self-response (improvement of reading the Qur'an, learning from mistakes, learning). from others, advising oneself, must be better than yesterday, use free time to memorize, and have fun.) External factors are the support from the closest people.

The formation of student selfregulation is also influenced by the existence of supporting factors, namely the intention, determination of heart, goals, and selfmotivation to memorize the Qur'an, and inhibiting factors, namely the arrival of laziness, finding difficult vocabulary, use of gadgets, and negative mood disorders.

\section{References}

Abd Moqsith Ghazali, L. A., \& AbsharAbdalla, U. (2009). Meodologi Studi AlQur'an. PT Gramedia Pustaka Utama.

Al-Munawar, S. A. H. (2002). al Qur'an membangun tradisi kesalehan hakiki. Ciputat Pers.

Alwisol. (2012). Psikologi Kepribadian (edisi revisi). UMM Prees.

Amin, M. (2016). Jatuh Cinta pada Al-Quran. Elex Media Komputindo. 
Bandura, A. (1989). Human agency in social cognitive theory. American Psychologist, 44

1175-1184. https://psycnet.apa.org/doi/10.1037/0003 -066X.44.9.1175

Baumeister, Roy F \& Vhos, K. (2007). SelfRegulation, Ego Depletion, and Motivation. Social and Personality Psychology Compass, 1(1), 115-128., 1(1)(Self-Regulation, Ego Depletion, and Motivation), 115-128.

Cervone, D., \& Pervin, L. A. (2012). (2012). Kepribadian: Teori dan penelitian. (D. Penerj: Aliya Tusyani (ed.)). Salemba Humanika.

Chairani, L \& Subandi, S. (2010). Psikologi Santri Penghafal Al-Qur'an Peranan Regulasi Diri. Pustaka Pelajar.

Daulay, M. R. (2014). Studi pendekatan alquran Oleh: Muhammad Roihan Daulay. Jurnal Thariqah Ilmiah.

Hapidoh, S., Bukhori, B., \& Sessiani, L. A. (2019). The Effect of Self-Regulation and Peer Attachment on Adversity Quotient in Quran Reciter Students. Psikologika. Jurnal Pemikiran Dan Penelitian Psikologi, 24(2), 167.

Lasmiati, L. (2018). (2018). Perbedaan regulasi diri dalam menyelesaikan skripsi bagi santri: studi pada santri penghafal Al-Quran dan non penghafal Al-Qur'an di Pondok Pesantren Sunan Drajat Lamongan (Disertasi). UIN Walisongo.

Lukmawati, L., Tanjung, F., \& Supriyanto, J. (2018). Al-qur'an itu menjaga diri: peranan regulasi diri penghafal al-qur'an. Psikis: Jurnal Psikologi Islami. https://doi.org/10.19109/psikis.v3i3.1754

Marza, S. E. (2017). Regulasi Diri Remaja Penghafal al-Qur'an di Pondok Pesantren al-Qur'an Jami'atul Qurro' Sumatera Selatan. INTELEKTUALITA. https://doi.org/10.19109/intelektualita.v6 i1.1306

Muhsin, A., \& As-Sirjani, R. (2017). Orang
Sibuk pun Bisa Hafal Al-Qur'an. PQS Publishing.

Rachmah, D. N. (2015). Regulasi Diri dalam Belajar pada Mahasiswa yang Memiliki Peran Banyak. Jurnal Psikologi. https://doi.org/10.22146/jpsi.6943

Sa'dulloh, S. Q. (2008). 9 Cara Praktis Menghafal Al-Qur'an. . Gema Insani.

Setiyawati, Y. (2019). Regulasi diri mahasiswa ditinjau dari keikutsertaan dalam suatu organisasi. Empati-Jurnal Bimbingan Dan Konseling. https://doi.org/10.26877/empati.v6i1.411 5

Utami, A. F., \& Hidayat, S. (2017). Regulasi Diri Remaja Penghafal Al-Qur'an (Disertasi). UMS.

Wahyuni, E. N. (2012, September). Keefektifan teknik observasi diri dan mengubah dialog internal untuk meningkatkan kemampuan remaja mengelola marah.

Yusuf, S., \& Nurikhsan, J. (2013). Teori Kepribadian. PT. Remaja Rosdakarya.

Yasdar, M., \& Muliyadi, M. (2018). Penerapan Teknik Regulasi Diri (self-regulation) untuk Meningkatkan Kemandirian Belajar Mahasiswa Program Studi Bimbingan Konseling STKIP Muhammadiyah Enrekang. Edumaspul: Jurnal Pendidikan, 2(2), 50-60.

Zimmerman, B. J., \& Schunk, D. H. (Eds. ). (2001). Self-regulated learning and academic achievement: Theoretical perspectives. Routledge. 